\title{
Initial characteristics of koi herpesvirus and development of a polymerase chain reaction assay to detect the virus in koi, Cyprinus carpio koi
}

\author{
Oren Gilad ${ }^{1}$, Susan Yun ${ }^{1}$, Karl B. Andree ${ }^{1}$, Mark A. Adkison ${ }^{1}$, Amir Zlotkin ${ }^{2}$, \\ Herve Bercovier ${ }^{2}$, Avi Eldar ${ }^{3}$, Ronald P. Hedrick ${ }^{1, *}$ \\ ${ }^{1}$ Department of Medicine and Epidemiology, School of Veterinary Medicine, University of California, Davis, \\ California 95616, USA \\ ${ }^{2}$ Institute of Microbiology, Department of Clinical Microbiology, The Hebrew University-Hadassah Medical School, \\ Ein Karen, Jerusalem, Israel \\ ${ }^{3}$ Department of Poultry and Fish Diseases, The Kimron Veterinary Institute, Beit Dagan, Israel
}

\begin{abstract}
Since 1998, episodes of mass mortality have occurred in populations of common carp Cyprinus carpio carpio in Israel and in populations of koi Cyprinus carpio koi in Israel and the USA. A herpesvirus isolated from infected fish has been shown in experimental studies to induce disease and mortality similar to those observed in outbreaks at infected farms. Initial characteristics of the virus show that it is clearly different from Herpesvirus cyprini (CHV), the most commonly known herpesvirus from cyprinid fish. The koi herpesvirus (KHV) has 31 virion polypeptides. Twelve of the virion polypeptides of KHV have similar molecular weights to those of $\mathrm{CHV}$ and 10 are similar to those of channel catfish virus (CCV). Both virion polypeptide and restriction fragment length polymorphism analyses of genomic DNA showed that the first KHV isolates from Israel and the USA were identical. In contrast, the genomic DNA restriction fragments clearly distinguish KHV from CHV and $\mathrm{CCV}$. A polymerase chain reaction (PCR) assay to detect the virus in koi tissues was developed with sequences obtained from 1 restriction fragment of KHV DNA. The PCR assay effectively detected a 484 base pair sequence from KHV but did not amplify genomic DNA from either CHV or CCV. The PCR assay detected as little as 1 pg of KHV DNA mixed with $100 \mathrm{ng}$ of host DNA. Viral sequences were amplified from koi obtained from field collections and from koi that were experimentally exposed to $10^{2} \mathrm{TCID}_{50} \mathrm{ml}^{-1}$ of KHV via the waterborne route. All KHV exposed fish dying of infection between 8 and $10 \mathrm{~d}$ post exposure or surviving to $14 \mathrm{~d}$ post exposure were found to be positive by PCR, while unexposed control koi were all negative. The assay also showed the presence of KHV DNA in tissues of koi obtained from farms in Israel. The PCR assay should assist virus isolation procedures and histologic and electron microscopic analyses now commonly used to detect KHV infection. Current studies are examining the possibility of using the PCR to detect KHV DNA in live fish and the relative sensitivity and specificity of the KHV PCR assay compared with other diagnostic tests.
\end{abstract}

KEY WORDS: Koi · Common carp · Herpesvirus · Koi herpesvirus · Polymerase chain reaction

\section{INTRODUCTION}

Recent and mass mortality among fingerling, juvenile and adult common carp Cyprinus carpio carpio, and fancy carp or koi Cyprinus carpio koi has occurred in

${ }^{*}$ Corresponding author. E-mail: rphedrick@ucdavis.edu the USA, Western Europe and Israel (Bretzinger et al. 1999, Neukirch et al. 1999, Body et al. 2000, Hedrick et al. 2000). Several of these outbreaks are now suspected to be due to systemic infections with a newly recognized virus, the koi herpesvirus (KHV; Hedrick et al. 2000). Mortality begins typically 7 to $10 \mathrm{~d}$ following exposure of previously uninfected koi and common carp 
to suspected carrier fish and the cumulative mortality can approach $100 \%$ over a 2 to 3 wk period (Hedrick et al. 2000). Infected fish have pale and irregular coloration of the gills and skin, with few other external or internal signs. Microscopic examinations of the liver, spleen and kidney show necrosis of parenchymal cells and numerous macrophages with ingested cellular debris (Hedrick et al. 2000). Intranuclear inclusions may be evident in infected cells, and virions with characteristic herpesvirus morphology can be observed directly in these tissues (Bretzinger et al. 1999, Body et al. 2000, Hedrick et al. 2000). Hedrick et al. (2000) was able to isolate a herpesvirus (KHV) using a koi fin (KF-1) cell line that was identical to the virus found by electron microscopy in infected fish tissues. Furthermore, they showed that juvenile koi exposed to KHV by bath challenges developed disease and experienced mortality that was similar to that observed in the field.

The virus recovered from dying carp by Hedrick et al. (2000) appears to be a newly recognized herpesvirus that differs from cyprinid herpesvirus $(\mathrm{CHV})$, the only other previously isolated herpesvirus from koi and common carp. CHV was initially observed by Schubert (1966) by electron microscopy and later isolated and more thoroughly characterized by Sano et al. (1985a, b). CHV was found to cause both papillomatous skin growths or carp pox lesions in older fish and systemic and lethal infections in koi and common carp less than 2 mo in age (Sano et al.1991a).

The rapid spread of KHV is presumably related to the worldwide trade and showing of koi or fancy carp, since most of these movements occur in the absence of any health examinations or certifications. The transport of pathogens with live fish has been a major concern for those responsible for fish health regulations that try to balance the need for trade with disease control programs (Hedrick 1996). Inspection of fish before shipment or at the farm sites where they are produced is one effective measure to prevent the spread of serious pathogens. These control programs rely on sensitive and specific detection procedures for the pathogens of concern. With KHV, the only current diagnostic procedure is isolation of the virus using the KF-1 cell line, a procedure that requires 7 to $10 \mathrm{~d}$ incubations at $20^{\circ} \mathrm{C}$ (Hedrick et al. 2000). This method is effective in detecting virus during mortality episodes but appears inadequate to detect KHV among carriers, the fish now believed responsible for the spread of KHV. In this study we provide initial characteristics of the viral genome and virion proteins of KHV isolated from koi in the USA (KHV-U) and Israel (KHV-I) compared with CHV. Using the newly obtained DNA sequence data from these comparisons, we developed and have initially tested a polymerase chain reaction (PCR) assay for detecting KHV in fish tissues.

\section{MATERIALS AND METHODS}

Source of fish. Koi were obtained from farms in Israel and retailers in the USA that reported suspected KHV outbreaks or from experimental trials in our laboratory. Koi used in the experimental trial were approximately $2 \mathrm{yr}$ of age, and had a mean weight of $0.25 \mathrm{~kg}$ and a mean fork length of $13 \mathrm{~cm}$. The fish used in the experimental trial were reared in a closed system (i.e. no new fish had entered the facility in the previous $10 \mathrm{yr}$ ) at a commercial ornamental fish producer. Fish were transported to the fish health laboratory at the University of California in Davis, California, and held in 130 l aquaria receiving $23^{\circ} \mathrm{C}$ water at $1.81 \mathrm{~min}^{-1}$. The fish were fed a commercial koi ration at $1 \%$ body weight $\mathrm{d}^{-1}$.

Viruses and cell lines. The KHV-I used in this study was isolated from adult koi experiencing mass mortality in Israel in 1998 (Hedrick et al. 2000). The KHV-U was recovered from a similar outbreak among adult koi in the eastern USA in 1998 (Hedrick et al. 2000). The CHV in this study was a gift from Dr. T. Sano and Dr. H. Fukuda, Tokyo University of Fisheries. The channel catfish herpesvirus (CCV) strain CA80-5 serving as the unrelated herpesvirus control was isolated from an epizootic among juvenile channel catfish Ictalurus punctatus in California in 1980 (Arkush et al. 1992). Both KHV isolates and CHV were propagated in the KF-1 cell line as described by Hedrick et al. (2000). The channel catfish ovary cell (CCO) line was propagated in minimum essential medium (MEM) supplemented with $7.5 \%$ fetal bovine serum (FBS), 50 IU penicillin $\mathrm{ml}^{-1}, 50 \mathrm{\mu g}$ streptomycin $\mathrm{ml}^{-1}$ and $2 \mathrm{mM} \mathrm{L}-$ glutamine. The FBS concentrations of the growth medium were reduced to $2 \%$ (MEM-2) when $\mathrm{CCO}$ cells were infected with CCV or when KF-1 cells were inoculated with $\mathrm{KHV}$. Cells were incubated at $25^{\circ} \mathrm{C}$ following inoculation with $\mathrm{CCV}$ or at $20^{\circ} \mathrm{C}$ for $\mathrm{KHV}$.

The isolation of KHV from fish tissues was as described by Hedrick et al. (2000). Replicate wells of a 12-well tissue culture plate containing monolayers of KF-1 cells were inoculated with $0.2 \mathrm{ml}$ of a 1:50 dilution $(\mathrm{v} / \mathrm{v}$ or $\mathrm{w} / \mathrm{v})$ of the original tissue extract. After an adsorption period of $1 \mathrm{~h}, 2 \mathrm{ml}$ of MEM-2 containing 0.015 M N-2-hydroxyethyl-piperazine-N-2-ethane sulfonic acid (HEPES), $50 \mathrm{IU}$ of penicillin $\mathrm{ml}^{-1}, 50 \mu \mathrm{g}$ streptomycin $\mathrm{ml}^{-1}$ and $2 \mathrm{mM}$ L-glutamine was added to each well and the plates were incubated at $20^{\circ} \mathrm{C}$. The plates were observed daily for evidence of cytopathic effects (CPE) over $21 \mathrm{~d}$. Concentrations of KHV were estimated by the method of Reed \& Meunch (1938) by $50 \%$ end point tissue culture infective dose $\left(\mathrm{TCID}_{50}\right)$ analysis in 96-well plates containing KF-1 cells incubated at $20^{\circ} \mathrm{C}$ for $14 \mathrm{~d}$.

Virus purification and DNA extraction. After the $\mathrm{CPE}$ was complete, flasks inoculated with each of the 
viruses were frozen at $-80^{\circ} \mathrm{C}$ for at least $24 \mathrm{~h}$. After thawing at room temperature, cells and culture media were collected. Cell debris was separated from the culture medium by centrifugation at $3500 \times g$ for $20 \mathrm{~min}$ at $10^{\circ} \mathrm{C}$. The pellet was placed into a Dounce homogenizer (Pyrex) with $10 \mathrm{ml}$ of MEM-2. After 10 to 15 strokes, the homogenate was again centrifuged at $3500 \times g$ for $20 \mathrm{~min}$ at $10^{\circ} \mathrm{C}$. The pellet was discarded and the supernatant centrifuged for $90 \mathrm{~min}$ at $95300 \times \mathrm{g}$ at $10^{\circ} \mathrm{C}$. The virus pellet was suspended in $1 \mathrm{ml}$ TNE (50 mM Tris- $\mathrm{HCl}, 150 \mathrm{mM} \mathrm{NaCl}, 1 \mathrm{mM}$ disodium ethylene diaminetetracetic acid [EDTA], pH 7.5) and placed in a Dounce homogenizer, and after 10 to 15 strokes the suspension was layered onto a 10 to $60 \%$ $(\mathrm{w} / \mathrm{w})$ linear sucrose gradient in TNE. After centrifugation at $77000 \times g$ for $18 \mathrm{~h}$ at $10^{\circ} \mathrm{C}$, 2 visible bands near the bottom of the tube were collected, diluted in fresh TNE and centrifuged at $151000 \times g$ for $1 \mathrm{~h}$ at $10^{\circ} \mathrm{C}$ (Arkush et al. 1992). The virus pellet was placed directly into either TNE at a final protein concentration of $1 \mathrm{mg} \mathrm{ml}^{-1}$ for sodium dodecyl sulfate polyacrylamide gel electrophoresis (SDS PAGE) analyses (virion polypeptide analyses) or molecular biology grade water and treated with DNaseI and RNaseA at final concentration of $15 \mu \mathrm{g} \mathrm{ml}^{-1}$ each (genomic DNA comparisons) for $30 \mathrm{~min}$ at $37^{\circ} \mathrm{C}$.

Viral genomic DNA was extracted using a 25:24:1 phenol:chloroform:isoamyl alcohol (IAA) mixture, followed by ethanol precipitation. Briefly, purified virus was incubated with Proteinase $\mathrm{K}$ in the presence of lysis buffer for $3 \mathrm{~h}$ at $56^{\circ} \mathrm{C}$ followed by direct temperature shifting to $70^{\circ} \mathrm{C}$ for $20 \mathrm{~min}$ for inactivation and then treated with IAA. A 0.1 volume of $3 \mathrm{M}$ sodium acetate was added to the aqueous phase following IAA extraction followed by 2.5 volumes of cold $95 \%$ ethanol. The mixture was incubated overnight at $-70^{\circ} \mathrm{C}$, followed by centrifugation at $15000 \times g$ to precipitate the DNA. The supernatant was removed and the pellet was washed with $1 \mathrm{ml}$ of cold $70 \%$ ethanol and then air-dried for $5 \mathrm{~min}$. TE buffer was added and the DNA pellet was incubated for $5 \mathrm{~min}$ at $37^{\circ} \mathrm{C}$ to dissolve the DNA. DNA concentrations were determined by spectrophotometer (GeneQuant II, Pharmacia Biotech) and the samples were stored at $-20^{\circ} \mathrm{C}$.

Analysis of virion polypeptides. Purified virus (1 mg protein $\mathrm{ml}^{-1}$ ) in TNE was mixed 1:1 with $2 \times$ sample application buffer, heated to $100^{\circ} \mathrm{C}$ for $2 \mathrm{~min}$, then centrifuged for $2 \mathrm{~min}$ at $16000 \times g$. Virion polypeptides were separated by SDS-PAGE under reducing conditions in $12 \%$ Bio-Rad Ready Gels (Bio-Rad) according to the system of Laemmli (1975). Novex Mark-12 ${ }^{\mathrm{TM}}$ molecular weight standards (Novex) were included in each gel. After electrophoresis, the gels were stained with Coomassie blue G-250 and the approximate molecular weight of the virion polypeptides was estimated by their mobility relative to the molecular weight standards.

KHV restriction fragment length polymorphism (RFLP) comparisons with CHV and CCV. For RFLP comparisons, 1 to $2 \mu \mathrm{g}$ of viral DNA from purified preparations of KHV-U, KHV-I, CHV and CCV was incubated with $10 \mathrm{U}$ of either KpnI or SacI endonuclease for $1 \mathrm{~h}$ at $37^{\circ} \mathrm{C}$. DNA fragments were separated by electrophoresis on $0.8 \%$ agarose gels and observed after staining with $1 \%$ ethidium bromide.

Cloning and sequencing of restriction fragments. An aliquot of purified KHV DNA was incubated with $10 \mathrm{U}$ of KpnI and $S a c I$ endonucleases. The resulting DNA fragments were inserted into the $\mathrm{pGEM}^{\circledR}-7 \mathrm{Zf}(+)$ plasmid that was then used to transform DH5 $\alpha$ Escherichia coli cells. The bacterial cells were grown on trypticase yeast extract agar at $37^{\circ} \mathrm{C}$ in the presence of ampicillin (200 $\left.\mu \mathrm{g} \mathrm{ml} \mathrm{m}^{-1}\right), \mathrm{X}$-gal isopropyl-[[beta]]-Dgalactopyranoside (IPTG) and for screening of clones. White colonies were selected and plated on reference media plates, and the transformants bearing KHV inserts were screened by PCR using SP6/T7 primers flanking the insert site (Sambrook et al. 1989). The sequence of 1 insert (1450 base pairs, bp) was obtained by fluorescently labeled dideoxy terminator sequencing using an ABI 377 automated DNA sequencer (Applied Biosystems).

Primer selection and oligonucleotide synthesis. Oligonucleotides to be used as primers in the PCR assay were selected and then tested for possible secondary structure and self-complementarity using Amplify software (University of Wisconsin Genetics). Oligonucleotides were synthesized commercially (Gibco BRL).

Optimization of KHV PCR assay. Initial PCR parameters were established that provided amplification of a 484 bp product corresponding to sequences obtained from the cloned KHV DNA KpnI/SacI fragment. To optimize the PCR assay, varying concentrations of primers from 20 to 40 pmol, Taq DNA polymerase from 1 to $2 \mathrm{U}, \mathrm{MgCl}_{2}$ from 0.5 to $2.5 \mathrm{mM}$ and tetramethyl ammonium chloride from $5 \mu \mathrm{M}$ to $20 \mathrm{mM}$ were tested with a known positive sample of purified KHV DNA. A range of annealing temperatures and different numbers of cycles of amplification were also examined.

Following optimization of the PCR the $484 \mathrm{bp}$ amplified DNA products from both fish collected from the field and following experimentally induced KHV infections were sequenced and aligned to the original sequence of the KpnI/SacI restriction fragment using Mac DNAsis (Hitachi).

Ability of PCR to discriminate between related herpesviruses. The ability of the newly developed PCR to discriminate KHV from other herpesviruses was tested. A total of $50 \mathrm{ng}$ of DNA obtained from purified KHV-I, 
KHV-U, CHV, CCV or uninfected KF-1 cells was used as a template for the PCR assay. The resulting amplified products were analyzed on agarose gels after staining with ethidium bromide as previously described. As positive controls for the $\mathrm{CHV}$ and $\mathrm{CCV}$ DNA, PCR assays specific for each virus were conducted on the same DNA samples used in the KHV PCR. The primers and sequence for the CHV PCR were kindly provided by Dr. H. Fukuda, Tokyo University of Fisheries (unpubl.) and the expected size of the product is $435 \mathrm{bp}$. The PCR for CCV was provided by Dr. L. Hanson, Mississippi State University (unpubl.) and the product amplified by this assay is $279 \mathrm{bp}$.

Level of detection. The least amount of target DNA detectable with the optimized PCR assay was determined using 10-fold serial dilutions from $10 \mathrm{ng}$ to $0.001 \mathrm{pg}$ of KHV DNA. This dilution series was tested in the PCR at 4 different annealing temperatures (i.e. $55,60,65$ and $68^{\circ} \mathrm{C}$ ). An estimation of the level of detection of KHV DNA sequences that might be expected in infected tissues was evaluated by analyzing amplicons obtained by PCR analyses of dilutions of purified KHV DNA with and without prior mixing with $100 \mathrm{ng}$ of host (koi) DNA.

PCR examinations of fish exposed to KHV in the field and laboratory. Thirty-five koi from farms or retailers that experienced unexplained mortality were examined for the presence of KHV by isolation of the virus on the KF-1 cell line and detection of KHV DNA sequences by the PCR assay. In the laboratory trial, the presence of KHV was examined by the same procedures among koi exposed to the virus or control koi not exposed to the virus. Forty koi were divided into 2 equal groups. The experimental group received $6.3 \times 10^{3} \mathrm{TCID}_{50} \mathrm{ml}^{-1}$ of $\mathrm{KHV}$ in MEM-2 through waterborne exposure in $100 \mathrm{l}$ of $23^{\circ} \mathrm{C}$ well water for $1 \mathrm{~h}$. The second group of fish was treated in the same manner but only with MEM-2. After exposure, fish were transferred to $130 \mathrm{l}$ aquaria receiving flow through $23^{\circ} \mathrm{C}$ well water at a rate of $1.81 \mathrm{~min}^{-1}$. Fish were fed a commercial diet each day. Fish were observed twice daily following virus exposure. The kidney, spleen and gill were collected from experimentally infected fish and processed by standard virological methods (Ganzhorn \& LaPatra 1994). For PCR analyses $1 \mathrm{~g}$ of the kidney, spleen and gill was removed and DNA from the tissues was extracted as previously described. A total of $100 \mathrm{ng}$ of this DNA was used in each PCR assay. Dead fish were examined for virus isolation immediately and samples for PCR were stored at $-70^{\circ} \mathrm{C}$. At $21 \mathrm{~d}, 10$ control fish were examined for the presence of KHV by virus isolation and PCR analysis. At 4 mo post exposure all remaining fish in the exposed and control groups were killed by overdose with 500 ppm of tricaine methanosulfonate (MS-222) and examined for KHV by virus isolations and by PCR assays.

\section{RESULTS}

\section{Virion polypeptides of KHV-I, KHV-U, CHV and CCV}

The virion polypeptide profiles of KHV isolates were distinctly different from those of $\mathrm{CHV}$ and $\mathrm{CCV}$ (Fig. 1). Depending on the virus, 23 to 35 polypeptides were present. KHV possessed 31 polypeptides with 12 sharing the same molecular weight as those found in $\mathrm{CHV}$, while 10 polypeptides of KHV shared a similar size to those of CCV. A comparison of the KHV-I and KHV-U isolates showed no significant differences in the number or size of virion polypeptides (Fig. 1).

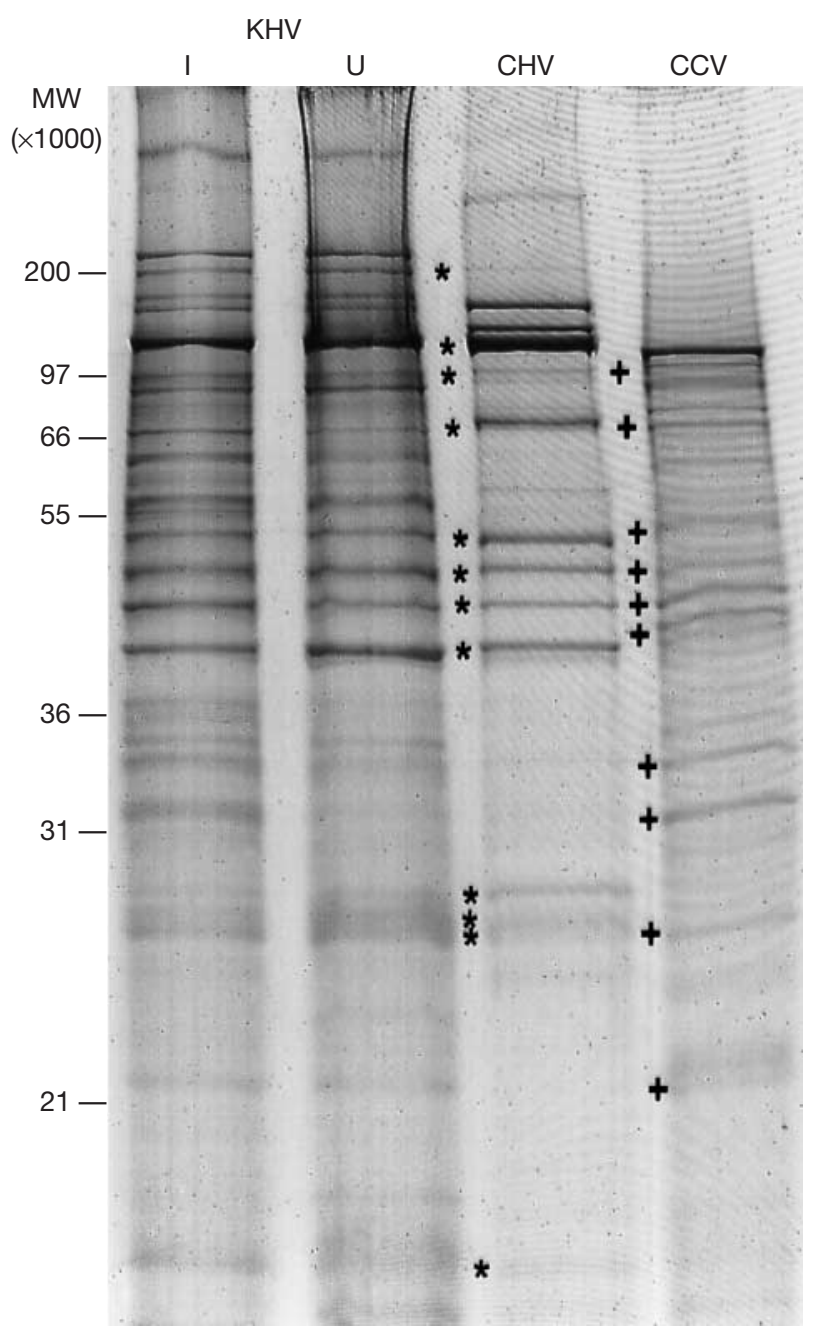

Fig. 1. Comparison of the virion polypeptides of 2 isolates of koi herpesvirus (KHV), one from Israel (KHV-I) and the second from the USA (KHV-U), with those of the cyprinid herpesvirus (CHV) and channel catfish herpesvirus (CCV). The bands marked with $(*)$ are shared between KHV and $\mathrm{CHV}$ and those with (+) are similar between KHV and CCV. MW: molecular weight 


\section{RFLP analysis of KHV-I, KHV-U, CHV and CCV}

The genomic DNA of KHV was found to provide a unique and clearly distinguishable RFLP from that of CHV or CCV when cut with KpnI or SacI (Fig. 2). There were no apparent differences between the RFLP of KHV-U and that of KHV-I (Fig. 2). The largest molecular weight Kpn I fragments were from KHV while the lowest molecular weight fragments were found with CCV. Similar sized high molecular weight restriction fragments were generated by SacI treatments of both KHV and CHV, and these fragments were generally larger than those of $\mathrm{CCV}$ (Fig. 2).

\section{Optimization of KHV PCR assay}

The optimal parameters for the PCR assay were obtained by sequential testing of target DNA from purified virus and experimentally and naturally exposed koi. The conditions that provided the strongest amplification of the specific $484 \mathrm{bp}$ fragment were as fol- lows: cocktail: $2 \mathrm{mM} \mathrm{MgCl}_{2}, 1 \times$ buffer, $400 \mu \mathrm{M}$ deoxynucleotide triphosphate, 30 pmol primers, $1 \mathrm{U}$ Taq polymerase; template: 70 to $100 \mathrm{ng} \mathrm{DNA}_{\text {; cycling con- }}$ ditions: $95^{\circ} \mathrm{C}$ for $5 \mathrm{~min}$ and then 39 cycles of $94^{\circ} \mathrm{C}$ for $1 \mathrm{~min}, 68^{\circ} \mathrm{C}$ for $1 \mathrm{~min}, 72^{\circ} \mathrm{C}$ for $30 \mathrm{~s}$ and finally $72^{\circ} \mathrm{C}$ for 7 min.; forward primer: KHV9/5F 5'-GACGACGCCGGAGACCTTGTG-3'; reverse primer: KHV9/5R 5'CACAAGTTCAGTCTGTTCCTCAAC-3'.

\section{Ability of PCR to discriminate KHV from other herpesviruses}

The PCR assay under the optimal conditions amplified a $484 \mathrm{bp}$ fragment of DNA from KHV-I and KHVU but not from CHV, CCV or the KF-1 cell line (Fig. 3). At lower annealing temperatures (e.g. $55^{\circ} \mathrm{C}$ ) there was a weak amplification of a similar sized product from CCV DNA. However, when annealing temperatures were increased to between 60 and $68^{\circ} \mathrm{C}$, there was no amplification of CCV DNA. The sequence of the 484 bp amplicon from the KHV PCR was deposited in GenBank (accession no. AF411803).
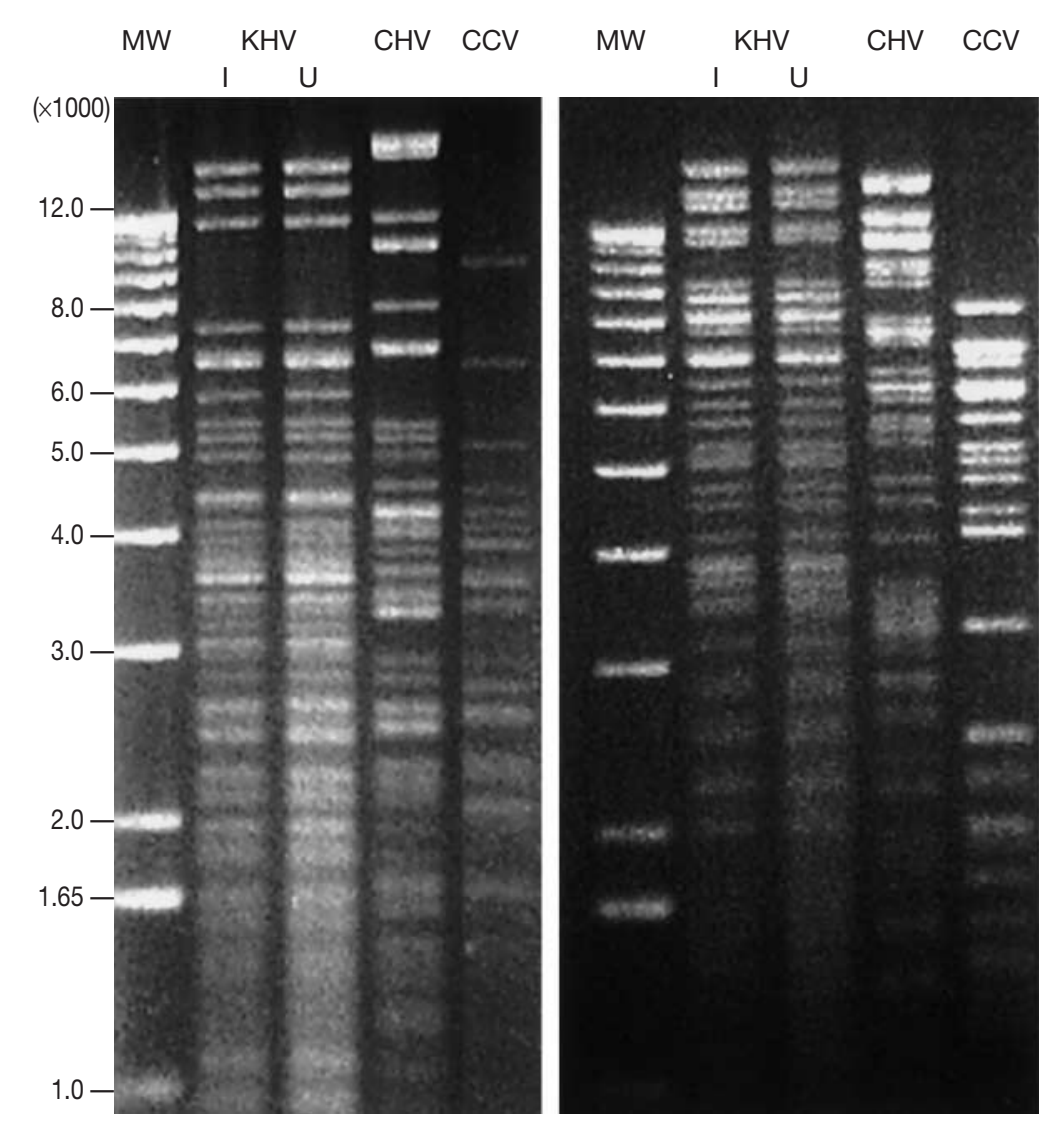

Fig. 2. Restriction fragment length polymorphisms (RFLP) resulting from digestion of the viral DNA from KHV from Israel (KHV-I) and the USA (KHV-U), CHV and CCV with either (A) Sac I or (B) Kpn I. DNA molecular weight (MW) standards are found in the far left lanes of each agarose gel

\section{Level of detection of KHV DNA in fish tissues}

The lowest amount of KHV DNA detected was $1 \mathrm{pg}$ when the annealing temperature in the PCR was $68^{\circ} \mathrm{C}$. The viral DNA was detected when the DNA sample was from purified virus or when $100 \mathrm{ng}$ of DNA from uninfected fish tissues was included in the reaction (Fig. 4).

\section{Detection of KHV in koi by PCR assay}

Koi from one source in the USA showed no evidence for KHV by either virus isolation or PCR assay. However, $3 \mathrm{KHV}$ isolates were obtained from koi using the KF-1 cells at 3 additional sites and 6 of 12 fish examined from these same sites were positive by PCR (Table 1). KHV was not isolated from frozen koi tissues obtained from 7 sites in Israel although a PCR analysis found that 4 of the sites had a least 1 positive fish (Table 1). We examined the sequence of the PCR products from 3 fish from the field ( 2 fish from Israel and 1 from the USA) and 2 fish from the experimental exposure study and all were identical to that of the original KHV DNA fragment used to develop the PCR. 


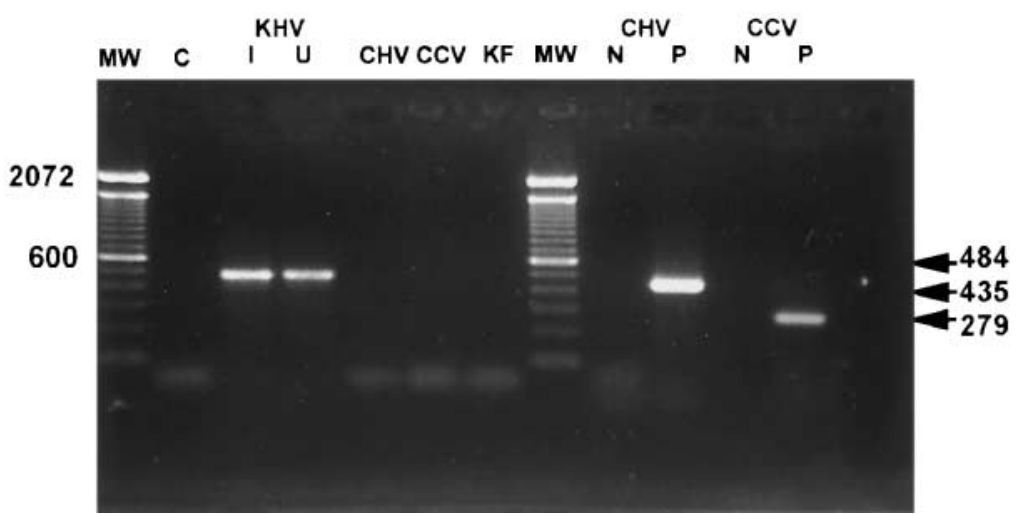

Fig. 3. Results from the polymerase chain reaction (PCR) assay for KHV when purified viral DNA was examined from KHV isolates from Israel (KHV-I) and the USA (KHV-U) with purified viral DNA from CHV and $\mathrm{CCV}$. On the same gel are the results from the amplification of purified viral DNA from CHV and CCV used in the KHV PCR as tested with specific PCR assays for $\mathrm{CHV}$ and $\mathrm{CCV}$, respectively. The negative controls $(\mathrm{C}$ or $\mathrm{N})$ were water only and the positive control $(\mathrm{P})$ was DNA from purified virus. Molecular weight (MW) markers were included in the gel and the sizes of the specific PCR products are indicated by arrows with the presence of KHV, a newly recognized herpesvirus (Hedrick et al. 2000). Initial characteristics of KHV, principally differences in antigenic properties and the pathogenesis of the disease in larger koi and common carp, suggested that the virus was not CHV, the most commonly encountered herpesvirus in carp (Hedrick et al. 2000). Further characterization of KHV-I and KHV-U by examination of virion polypeptides and RFLP analyses of genomic DNA indicates that the agents are identical but clearly different from $\mathrm{CHV}$ and CCV. In addition, sequence data from a restriction fragment of KHV has been used to develop a PCR assay that can detect the agent in naturally and experimentally exposed koi. PCR provides a new approach to detecting $\mathrm{KHV}$ that appears to be more effective than routine virus isolation on the KF-1 cell line. PCR also detects both KHV-I and KHV-U, and this further indicates the similarity of the 2 isolates.

Eleven fish exposed to KHV in the laboratory trial died between 10 and $22 \mathrm{~d}$ post exposure. The virus was isolated from 9 of 11 exposed fish that died but not from 2 dead fish that were severely autolyzed at the time of collection. All KHV exposed fish that died were positive by PCR assay (11 of 11). KHV was not isolated, nor were survivors of the KHV exposure positive by $\mathrm{PCR}$ at 4 mo. There was no evidence of KHV by virus isolation or PCR assay among 10 control fish examined at $21 \mathrm{~d}$ or among the remaining control fish examined at $4 \mathrm{mo}$. There were no indications of skin abnormalities, including papillomas, on any surviving KHV exposed fish.

\section{DISCUSSION}

Recent and mass mortality among koi and common carp in both the USA and Israel has been associated

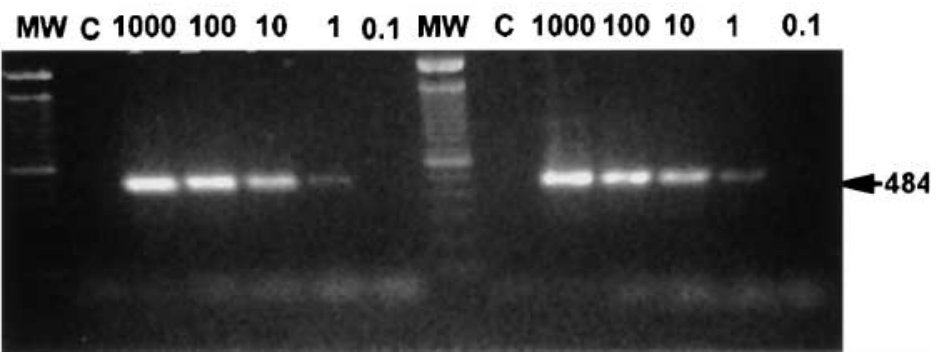

Fig. 4. KHV PCR assay as applied to serial 10-fold dilutions of KHV DNA beginning with $1000 \mathrm{pg}$ and ending with $0.1 \mathrm{pg}$. The KHV DNA was either amplified without host DNA (right half of the gel) or mixed with $100 \mathrm{ng}$ of host DNA (left half of the gel)
The virion polypeptide profiles of KHV-I and KHV-U were indistinguishable and this provides further support that the agents are identical. There were similarities among several virion polypeptides between KHV and $\mathrm{CHV}$ that suggest that these agents are more similar to each other than either is to a third herpesvirus (CCV) from channel catfish. The presence of certain common polypeptides may be due in part to nonstructural components (some of which may be of cellular origin) that may be copurified or be trapped by virions (Spear \& Roizman 1972), but it was clear that several unique polypeptides were present in KHV that distinguished this virus from $\mathrm{CHV}$ or $\mathrm{CCV}$.

RFLP analyses of purified viral DNA further confirmed the identity of KHV from the USA and Israel and that KHV differs significantly from CHV and CCV. Analyses with 5 restriction enzymes (data from 3 enzymes not shown) showed no fragment polymorphisms between KHV-I and KHV-U. This provides strong evidence that significant DNA sequence homology is shared by the 2 isolates. RFLP analyses of genomic DNA have been used to compare related viruses or isolates of the same fish herpesviruses (Chousterman et al. 1979, Dixon \& Farber 1980, Colyer et al. 1986, Sano et al. 1991b). Although the profiles for single isolates of KHV from Israel and the USA were identical, we presume that a comparison of additional KHV isolates would indicate some potential polymorphisms. However, since both geographically distant isolates appear to be identical, this argues for a common origin of the virus together with a rapid 
Table 1. Detection of koi herpesvirus (KHV) by virus isolation on koi fin (KF-1) cells or by polymerase chain reaction (PCR) assay. Fish were obtained from sources in the USA or Israel or from controlled laboratory exposures to KHV. Virus isolation was attempted from the kidney, spleen and gill of each fish. A fish was considered virus positive if virus was isolated from any tissue. For PCR assays DNA was extracted from the gill, kidney and spleen of each fish. A fish was considered positive if any 1 of the 3 individual tissue samples provided a positive signal

\begin{tabular}{|lccc|}
\hline Origin of fish & $\begin{array}{c}\text { Number } \\
\text { of fish }\end{array}$ & $\begin{array}{c}\text { Virus } \\
\text { isolation }\end{array}$ & PCR \\
\hline USA \#1 & 5 & 0 & 0 \\
USA \#2 & 8 & $13 \%(1 / 8)$ & $38 \%(3 / 8)$ \\
USA \#3 & 2 & $50 \%(1 / 2)$ & $50 \%(1 / 2)$ \\
USA \#4 & 2 & $50 \%(1 / 2)$ & $100 \%(2 / 2)$ \\
Israel \#1 & 3 & 0 & $33 \%(1 / 3)$ \\
Israel \#2 & 4 & 0 & $25 \%(1 / 4)$ \\
Israel \#3 & 2 & 0 & $50 \%(1 / 2)$ \\
Israel \#4 & 3 & 0 & $67 \%(2 / 3)$ \\
Israel \#5 & 2 & 0 & 0 \\
Israel \#6 & 3 & 0 & 0 \\
Israel \#7 & 1 & 0 & 0 \\
Laboratory: KHV & 11 & $82 \%(9 / 11)$ & $100 \%(11 / 11)$ \\
exposed (dead) & & & \\
Laboratory: KHV & 9 & 0 & 0 \\
exposed (survivors & & & \\
at 4 mo) & & & \\
\hline
\end{tabular}

spread from that source. Additional studies of more isolates of KHV may show patterns of spread for the virus, as has been shown for certain mammalian herpesviruses (Banks 1993).

The similarities between the disease caused by KHV in larger koi and that due to CHV in koi and common carp less than 2 mo in age are remarkable (Sano et al. 1991a, Hedrick et al. 2000). This has led to some speculation that KHV might be a more pathogenic variant of CHV now capable of attacking and killing larger fish. While we presume that the 2 viruses share certain genes or gene sequences, the PCR assay developed in this study and both the RFLP and virion polypeptide analyses argue against KHV being a variant of CHV. More complete comparisons of the 2 viruses that consider genome arrangement and sequence homologies that are in progress should further clarify their relationships. Both viruses share the similar property of being rather difficult or impossible to isolate using most commonly available cell lines (Sano et al. 1985a, Hedrick et al. 2000) and this has severely compromised diagnostic tests to detect the agents. The disease caused by KHV differs in 2 key characteristics from that caused by $\mathrm{CHV}$. KHV causes significant mortality among young, juvenile and adult fish, and there is no evidence of skin tumor formation in survivors of KHV infections.

Current diagnostic procedures for KHV include detection of typical clinical signs, characteristic micro- scopic lesions in the gills and internal organs, and isolation of the agent in the KF-1 cell line (Hedrick et al. 2000). These methods are effective when fish are dying of infection but, even then, virus isolation may be difficult or impossible if tissues are frozen. Detecting the virus among fish surviving KHV infections has not been possible, but these fish are presumably carriers since co-habitation with previously unexposed fish has been the principal means for spread of the virus. Development of a PCR assay was viewed as one method to overcome these diagnostic problems.

The PCR developed in this study was effective in detecting KHV in koi tissues from fish collected from the field and from controlled laboratory exposures to the virus. The gill, kidney and spleen provided equally strong PCR amplifications of KHV DNA. In contrast, virus isolation using the KF-1 cell line was less reliable with the gill than the kidney and spleen as seen particularly with the field samples from both the USA and Israel (Table 1). Gill tissues can be used for virus isolation but bacterial contamination may be encountered more frequently and there was no evidence that this tissue provided better virus isolation than from the kidney or spleen. Freezing tissues, which may be required in some circumstances, appeared to hinder virus isolation. We suspect that KHV survives poorly in frozen tissues and, with this in mind, virus isolations are best conducted on fresh tissues. This may explain why the frozen tissues sent from Israel to our laboratory yielded no isolates of KHV while live fish received from American sources did provide isolates on the KF1 cell line. Examination of freshly dead fish from the laboratory trial also provided isolates of KHV. The only exceptions were the 2 exposed fish that died and from which virus could not be recovered. These fish had been dead for at least $16 \mathrm{~h}$ (and were severely autolyzed) and this may explain the failed attempt to recover KHV on the KF-1 cell line. However, the PCR was effective in detecting KHV DNA from both of those dead fish and from frozen tissues received from Israel. Unfortunately, KHV could not be detected in virus exposed koi surviving for 4 mo post exposure by either virus isolation or PCR assay. This may indicate that kidney, spleen and gill are not sites where latent $\mathrm{KHV}$ is found or, alternatively, that our PCR assay does not have the needed level of detection for the amount of viral DNA that might be present in these tissues. Additional studies that subject previously exposed fish to stress and/or examination of additional tissues by PCR for KHV are underway. Although further testing is needed, these initial results suggest that the PCR assay for KHV is much more effective than virus isolation on tissue samples obtained from fish experiencing outbreaks even if the samples are compromised by autolysis or freezing. 
The latent phase of infection with herpesviruses, including those from fish, can make it difficult or impossible to isolate the virus from fish tissues (Wise et al. 1985, Boyle \& Blackwell 1991, Sano et al. 1993). However, the use of PCR or in situ hybridization has shown that DNA of CCV and CHV can be detected among suspected carrier fish in a range of tissues that may change over the course of infection (Boyle \& Blackwell 1991, Sano et al. 1993, Gray et al. 1999a,b). We presume that KHV, as seen with $\mathrm{CCV}$ and $\mathrm{CHV}$, establishes a latent infection among exposed koi and common carp and these fish, perhaps through periodic shedding of infectious virus, serve as the carriers by which virus is spread. Unfortunately, our first attempts to detect these carriers using the 3 target tissues (kidney, spleen, gill) in previously exposed koi in the laboratory were unsuccessful, suggesting that target DNA was below the $1 \mathrm{pg}$ detection limit of our PCR. We are examining in more detail the course of infection and other potential sites for KHV latency in exposed koi and are exploring more sensitive procedures for viral DNA detection including quantitative PCR assays.

The ability to detect KHV carriers will be a critical step in controlling KHV outbreaks. We are hopeful that this PCR assay can be used to detect KHV carriers using nonlethal sampling methods. If these approaches are effective with individual fish and the results can be combined with those obtained from health inspections of populations at the producer and retailer, control of KHV becomes possible. Additional laboratory studies are examining the pathogenesis of experimental infections of koi with KHV and the potential to use vaccination as a preventive measure to control the virus.

Acknowledgements. The authors wish to thank Dr. D. Weaver for the koi used in the experimental trials in this study. We also thank Ms J. Lau and Ms B. Braid for their technical support, and Dr. J.D.W Moran for critical review of the manuscript. The study was supported in part by the US-Israel BARD contract no US-3166-99.

\section{LITERATURE CITED}

Arkush KD, McNeill C, Hedrick RP (1992) Production and initial characterization of monoclonal antibodies against channel catfish virus. J Aquat Anim Health 4:81-89

Banks M (1993) DNA restriction fragment length polymorphism among British isolates of Aujeszky's disease virus: use of the polymerase chain reaction to discriminate among strains. Br Vet J 149:155-163

Body A, Lieffrig F, Charlier C, Collard A (2000) Isolation of virus-like particles from koi (Cyprinus carpio) suffering gill necrosis. Bull Eur Assoc Fish Pathol 20:87-88

Boyle J, Blackwell BS (1991) Use of the polymerase chain reaction to detect latent channel catfish virus. Am J Vet Res 52:1965-1968

Editorial responsibility: Jo-Ann Leong,

Corvallis, Oregon, USA
Bretzinger A, Fischer-Scherl T, Oumouna M, Hoffman R, Truyen U (1999) Mass mortalities in koi, Cyprinus carpio, associated with gill and skin disease. Bull Eur Assoc Fish Pathol 19:182-185

Chousterman S, Lacasa M, Sheldrick P (1979) Physical map of the channel catfish virus genome: location of sites for restriction endonucleases EcoRI, HindIII, HpaI and XbaI. J Virol 31:73-85

Colyer TE, Bowser PR, Doyle J, Boyle JA (1986) Channel catfish virus: use of nucleic acids in studying viral relationships. Am J Vet Res 47:2007-2011

Dixon RAF, Farber FE (1980) Channel catfish virus: physicochemical properties of the viral genome and identification of viral polypeptides. Virology 103:267-278

Ganzhorn J, LaPatra SE (1994) Virology I. General procedures. In: Thoesen JC (ed) Suggested procedures for the detection and identification of certain fin fish pathogens, 4th edn. American Fisheries Society, Fish Health Section, Bethesda

Gray LW, Williams JR, Griffin BR (1999a) Detection of channel catfish virus DNA in acutely infected channel catfish, Ictalurus punctatus (Rafinesque), using the polymerase chain reaction. J Fish Dis 22:111-116

Gray LW, Williams JR, Jordan RL, Griffin BR (1999b) Detection of channel catfish virus DNA in latently infected catfish. J Gen Virol 80:1817-1822

Hedrick RP (1996) Movement of pathogens with the international trade of live fish: problems and solutions. Rev Sci Tech Off Int Epiz 15:523-531

Hedrick RP, Gilad O, Yun S, Spangenberg JV, Marty GD, Nordhausen RW and 3 others (2000) A herpesvirus associated with mass mortality of juvenile and adult koi, a strain of a common carp. J Aquat Anim Health 12:44-57

Laemmli UK (1975) Cleavage of structural proteins during the assembly of the head bacteriophage T4. Nature 227:680-685

Neukirch M, Bottcher K, Bunnajirakul S (1999) Isolation of a virus from koi with altered gills. Bull Eur Assoc Fish Pathol 19:221-224

Reed LJ, Meunch HA (1938) A simple method of estimating fifty percent endpoint. Am J Hyg 24:493-497

Sambrook J, Fritch EF, Maniatis T (1989) Molecular cloning, a laboratory manual, Vol 1, 2nd edn. Cold Spring Harbor Laborarory Press, Cold Spring Harbor, p 1.74-1.84

Sano T, Fukuda H, Furukawa M, Hosoya H, Moriya Y (1985a) A herpesvirus isolated from carp papilloma in Japan. Fish Shellfish Pathol 32:307-311

Sano T, Fukuda H, Furukawa M (1985b) Herpesvirus cyprini: biological and oncogenic properties. Fish Pathol 10: 381-388

Sano T, Morita N, Shima N, Akimoto M (1991a) Herpesvirus cyprini: lethality and oncogenicity. J Fish Dis 14:533-543

Sano N, Honda R, Fukuda H, Sano T (1991b) Herpesviruscyprini restriction endonuclease cleavage profiles of the viral DNA. Fish Pathol 26:207-208

Sano N, Morkwake M, Hondo R, Sano T (1993) Herpesvirus cyprini: a search for viral genome in infected fish. J Fish Dis 16:495-499

Schubert GH (1966) The infective agent in carp pox. Bull Off Int Epiz 65:1011-1022

Spear PG, Roizman B (1972) Proteins specified by herpes simplex virus. Virus purification and structural proteins of the herpesvirion. J Virol 9:143-159

Wise JA, Bowser PR, Boyle JA (1985) Detection of channel catfish virus in asymptomatic adult catfish, Ictalurus punctatus (Rafinesque). J Fish Dis 8:417-424

Submitted: April 4, 2001; Accepted: September 11, 2001

Proofs received from author(s): January 3, 2002 